\title{
Brazilian National Solid Waste Policy Applied As a Tool to Enhance an University Campus Waste Management
}

\author{
Rodrigo Martins Moreira ${ }^{1}$, Tiago Balieiro Cetrulo ${ }^{1}$, Alejandra Daniela Mendizábal-Cortes ${ }^{1}$, Natalia Molina \\ Cetrulo $^{2} \&$ Tadeu Fabrício Malheiros ${ }^{1}$ \\ ${ }^{1}$ São Carlos School of Engineering, University of São Paulo, São Paulo, Brazil \\ ${ }^{2}$ School of Arts, Sciences and Humanities, University of São Paulo, São Paulo, Brazil \\ Correspondence: Rodrigo Martins Moreira, Sciences of Environmental Engineering Program, São Carlos School \\ of Engineering, University of São Paulo, São Paulo, Brazil. Tel: 55-16-98181-9666. E-mail: \\ moreirarmt@gmail.com
}

Received: July 10, $2017 \quad$ Accepted: July 29, 2017 Online Published: August 3, 2017

doi:10.5539/jms.v7n3p101 URL: http://doi.org/10.5539/jms.v7n3p101

\begin{abstract}
The aim of this work is to discuss the Brazilian National Solid Waste Policy potential to enhance Brazilian universities waste management by analyzing the University of São Paulo, Campus of São context in accordance with the national policy requirements. Universities in Brazil lack a legal instrument to strengthen its waste management, which brings this paper innovation by applying the Brazilian waste policy as a standardization instrument to adapt waste management at Brazilian higher education institutions. The research used a descriptive and qualitative approach, data were collected from literature review, university documents and semi structured interviews, a case study approach is used to analyze the campus solid waste management activities, procedures and operations inherent the. The main findings conclude that University of São Paulo waste policy is being deployed, based on Brazilian Solid Waste National Policy requirements, confirming it translation into a potential framework tool to support decision making for adequacy of environmentally sound management of Brazilian. Further studies are required ex-post the policy enactment to assess the impacts of the waste policy at the university impacts.
\end{abstract}

Keywords: sustainability culture, waste policy, environmental management

\section{Introduction}

Discussions regard sustainability is a key criterion for policies elaboration and execution, inserting goals for equity and social justice promotion, efficiency in the use of natural resources and economic prosperity, giving priority to society's present well-being, without compromising future generations (Belkhir, 2015; Broman \& Robert, 2017). Furthermore, private companies, public institutions and organized society have tackled to insert sustainability on daily activities and decision making over last decades in response to negative pressure on the environment where anthropic actions occur, such as exponential solid waste generation growth and inadequate disposal (Mallak et al., 2014; Mesjasz-Lech, 2014; Stark, \& Lindow, 2017).

University campuses can be faced as small cities (Alshuwaikhat \& Abubakar, 2008), due to their size, number of people, diversity of activities and consumption of natural resources. Nevertheless, universities, responsible for producing human resources, assume the role of facilitators of sustainability actions within society, through their teaching pillars, research, and outreach, where students, teachers, and staff are considered as urban agents with potential towards sustainability leadership (Mauser et al., 2013; Tom et al., 2012; Yuan \& Zuo, 2013).

In this perspective, in 2005, solid household waste generation in South America was $1.1 \mathrm{~kg}^{\text {. inhab }}{ }^{-1}$.day ${ }^{-1}$ (Hoornweg, Bhada-Tata, \& Perinaz, 2012, p. 9). Of $1.04 \mathrm{Kg}_{\mathrm{inhab}}{ }^{-1}$.day $^{-1}$, in the Southeast region, this value was 0.88 kg.inhab ${ }^{-1}$. day $^{-1}$ (Abrelpe, 2013, p. 28), and the University of São Paulo, Campus of São Carlos (USP-SC) generates $1.46 \mathrm{~kg}$.person ${ }^{-1}$.day $^{-1}$ of waste (Schalch, 2014). Following this tendency, universities waste generation is large and diversified, resulting from its end activities (Armijo de Vega, Ojeda Benítez, \& Ramírez Barreto, 2008; Baldwin \& Dripps, 2012; Smyth, Fredeen, \& Booth, 2010).

The Brazilian National Solid Waste Policy (PNRS) enactment in 2010, create a legal conceptual basis for new tools and establish goals for the country waste management systematization (Brazil, 2010). This policy requires city halls to elaborate the Municipal Plans of Integrated Management of Solid Waste (PMGIRS). Thus, 
universities in Brazil do not have a specific policy to standardize waste management.

This paper innovates by bringing the Brazilian National Solid Waste Policy requirements and applying them as a standardization instrument to adapt waste management at Brazilian higher education institutions, disseminating through their practices a culture that walks from the perspective of sustainability lenses.

The objective of this work is to discuss the PNRS' potential to enhance Brazilian universities waste management by analyzing the University of São Paulo, Campus of São context in accordance with the PNRS' requirements.

\section{Method}

The research used a descriptive-qualitative approach proposed by (Thomas \& Magilvy, 2011), which considers data aspects regarding credibility, applicability, consistency and neutrality. The research used data from documents and interviews to describe activities, procedures and interactions inherent to Solid Waste Management of the University of São Paulo, São Carlos campus (USP-SC) as well as a systematic literature research to construct the analysis basis.

Analyses were conducted accordingly to the PNRS requirements, describing what needed to be addressed by a university's solid waste management.

The initial stages of work analyzed the Solid Waste Inventory prepared by Schalch et al. (2014). This inventory has a diagnosis of the generation, and description of the waste management of USP-SC.

A case study was conducted (Baxter \& Jack, 2008), using semi structured interviews (Drever, 1995) conducted with key management process actors from within the USP São Carlos campus, these actors were questioned regarding management and operational aspects of campus processes, questions addressed issues regard How much waste is produced daily? Who deals with the disposal of urban waste? What is the standard procedure to deal with hazardous waste? What are the main challenges faced by the waste management inside this university? Etc. The interview stage was a key factor for observation and verification of the practice and application of documented processes found.

In addition, several papers developed at USP-SC campus by undergraduate students were used as information grants, from disciplines and scientific initiation projects, which provided data and discussed the sustainability theme within USP-SC.

\section{Results}

University campuses have food, housing, and transportation services, many have school hospitals and clinics, generating healthcare waste, as well as research laboratories that generates hazardous waste that needs specific disposal. Furthermore, in addition to teaching and research activities, campuses host various social and scientific events (Tangwanichagapong et al., 2017). These factors show the waste generation variety and consumption of natural resources (Baldwin \& Dripps, 2012). Thus, with enormous potential of socio-environmental impacts, the heterogeneity of university campuses, different land uses and activities, aggregated with the fact that universities have social responsibilities for society training and education, environmental management and sustainability in universities requires an approach different from cities.

In this context, universities need a high input of natural resources, with a very wide range of diversity, Figure 1 brings the example of USP-SC waste inputs and outputs. 

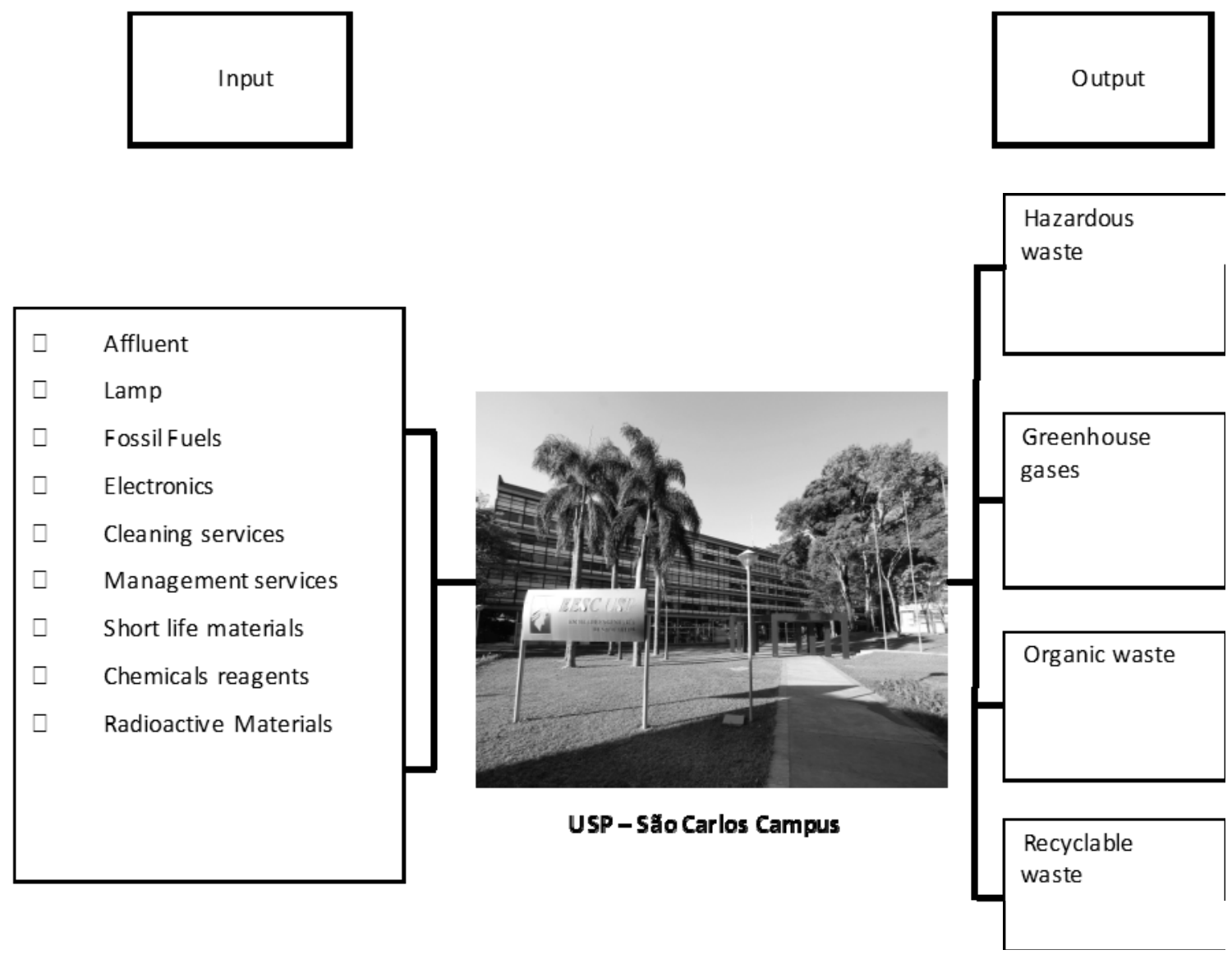

Figure 1. Waste inputs and outputs at USP-SC

Brazilian universities have daily complex operations that generate potentially polluting environmental impacts, and have been neglected in terms of a legislation tool that brings specific requirement regarding social and environmental responsibility (Adeniran et al., 2017).

In its management framework, universities have city halls, councils, committees, and various stakeholders included in their decision making. Thus, within its waste management, practices aimed at reduction, reuse, and recycling, as well as community re-education are of extreme importance, and within universities, actions that promote recycling practices are the most commonly applied (Armijo de Vega, Ojeda-Benítez, \& Ramírez-Barreto, 2003; Zain et al., 2012). Thus, it is necessary to reinforce the relationship between university and municipality, discussing innovative methodologies and planning strategies that contemplate equal civil benefit, with healthy environmental conditions, to the whole spectrum of society (Duarte, Gaudreau, Gibson, \& Malheiros, 2013).

\subsection{University of São Paulo Waste Management}

Solid waste management within university campuses, discussing and applying awareness-raising actions that deal with reduction, reuse and recycling have a direct influence of a university community consumption patterns and waste generation (Callewart \& Marans, 2013).

Since USP-SC has different profiles of teaching, research and outreach activities, being Institute of Chemistry, Institute of Physics, Institute of Computational Sciences and Mathematics, School of Engineering and Institute of Architecture and Urbanism, with different research and teaching profiles, translated in specific characteristics of generation and waste management, the PNRS requirement for the preparation of Solid Waste Management Plans for each unit of the university, such as for each dimension of a city, is applicable.

The University of São Paulo's Environmental Policies are in its final steps of development. One of these policies tackles waste management specifically, and it has its background support in Brazil's National Solid Waste Policy, setting prevention goals and predicting creation of plans and programs.

The USP Solid Waste Policy is a proposal of the University's Environmental Management Superintendence 
(SGA), an initiative of the USP dean's office. One of SGA's first actions was the elaboration of the USP Solid Waste Policy, by creating a committee with several teachers, staff, technicians and lawyers from within and outside the university. The meetings occurred periodically, mainly in the campus of USP-Piracicaba. The USP-SWP assumes the PNRS's premises, adapting itself to the university realities of each campus. One of the initiatives proposed by the USP-SWP is the decentralization of waste management, where all units, museums, departments, and campuses City Halls should prepare their Waste Management Plans.

The USP Solid Waste Policy (USP-SWP) requirements for Management plans are compared, in table 1, with PNRS' requirements.

Table 1. Parallel between the PNRS's and the USP-SWP's Waste Management Plans. Evaluation of the adequacy of actions performed by USP based on the investigator's observations and interview data (PNRS, 2010)

- Adequate; (O) Non adequate; ○ Needs Revision

\begin{tabular}{|c|c|c|}
\hline PGRS items required by PNRS (2010) & Draft PGRS proposed by USP & Evaluation \\
\hline "I - Description of the enterprise or activity" & $\begin{array}{l}\text { Description of the solid waste generator (Units, Museums, Integration } \\
\text { Bodies, Complementary Bodies and Campuses City Halls) as to: a) } \\
\text { location, b) population, c) activities developed, d) physical space, e) } \\
\text { administrative structure and f) Environmental aspects }\end{array}$ & • \\
\hline $\begin{array}{l}\text { "II - Diagnosis of solid waste generated or } \\
\text { managed, containing the source, volume and } \\
\text { characterization of the waste, including } \\
\text { related environmental liabilities" }\end{array}$ & $\begin{array}{l}\text { Diagnosis of the generation of solid waste following a methodology for } \\
\text { collecting information and tabulating the data related to the waste listed in } \\
\text { this policy; }\end{array}$ & $\bullet$ \\
\hline $\begin{array}{l}\text { "III - Observed the norms established by the } \\
\text { organs of the National Environmental } \\
\text { System(Sisnama), National Sanitary Vigilance } \\
\text { System (SNVS) and Unified System of } \\
\text { Attention for Agricultural Sanitation (Suasa) } \\
\text { and, if there is one, the municipal solid waste } \\
\text { management plan" }\end{array}$ & $\begin{array}{l}\text { Definition of the operational procedures related to solid waste management } \\
\text { stages under the responsibility of the generator, indicating those } \\
\text { responsible for solid waste management and collaborators; } \\
\text { Identification of the Technician duly qualified for the elaboration, } \\
\text { implementation, operationalization and monitoring of all the steps of the } \\
\text { solid waste management plan, including the control of tailings } \\
\text { environmentally adequate disposal }\end{array}$ & $\bullet$ \\
\hline $\begin{array}{l}\text { "IV - Identification of solutions shared or } \\
\text { shared with other generators" }\end{array}$ & $\begin{array}{l}\text { Identification of solutions shared or shared with other solid waste } \\
\text { generators }\end{array}$ & $\bullet$ \\
\hline $\begin{array}{l}\text { "V - Preventive and corrective actions to be } \\
\text { taken in situations of incorrect management or } \\
\text { accidents" }\end{array}$ & $\begin{array}{l}\text { Description of preventive and corrective actions to be performed in } \\
\text { situations of incorrect management or accidents (Contingency Plan); }\end{array}$ & $\bullet$ \\
\hline $\begin{array}{l}\text { "VI - Goals and procedures related to solid } \\
\text { waste reduction, in accordance with the } \\
\text { standards established by the organs of } \\
\text { Sisnama, SNVS and Suasa, reuse and } \\
\text { recycling" }\end{array}$ & Elaboratio & $\bullet$ \\
\hline $\begin{array}{l}\text { "VII - If applicable, actions related to shared } \\
\text { responsibility for the product life cycle, in the } \\
\text { form of art. } 31 \text { " }\end{array}$ & $\begin{array}{l}\text { Presentation of proposals and actions regarding shared responsibility for } \\
\text { the processes, products and services developed and consumed at the } \\
\text { University; }\end{array}$ & $\circ$ \\
\hline $\begin{array}{l}\text { "VIII - Sanitary measures for environmental } \\
\text { liabilities related to solid waste management" }\end{array}$ & Carried out by the USP-São Carlos Residues Inventory & $\bullet$ \\
\hline $\begin{array}{l}\text { "IX - Review period, observing, if applicable, } \\
\text { the term of validity of the respective license of } \\
\text { operation by the organs of Sisnama" }\end{array}$ & $\begin{array}{l}\text { The Solid Waste Management Plan shall be reviewed one year before the } \\
\text { end of the term of office of the Units, Museums, Integration Bodies, } \\
\text { Bodies } \\
\text { Complementary and City Halls } \\
\text { Elaboration of indicators to waste management performance monitoration. }\end{array}$ & • \\
\hline
\end{tabular}

It is observed that the text proposed by the USP-SWP waste management plans requirements is very similar to the PNRS. This is due to the committee that drew up this draft to have studied under the PNRS, which has a significant support, for the development of the policy for the university.

However, it is necessary to observe that the realities of university campuses are quite peculiar and may vary among the Higher Education Institution class, for example, many have laboratories with equipment that carry toxic and radioactive elements that demand special management, others, have researches with animals, generating residues such as carcasses, anatomical pieces, viscera, and corpses of animals suspected of infection. This emphasizes the need to translate this federal policy into a decision-making tool to specific cases of 
university campuses, although, the peculiarities of the plan and programs must be carefully studied and mentioned in policies text, of each campus, minimizing the possibility of gaps in their executions.

Many universities, as well as municipalities already have a waste management system, however, the elaboration and execution of a Waste Policy rise as a tool (Amasuomo \& Baird, 2016) to guide and support universities to institutionalize more environmentally friendly waste management. As shown by Zurbrügg, (2012) institutions that institutionalize environmental practices had this dimension strengthened.

\subsection{Case Study}

\subsubsection{Description of the USP São Carlos Case Study}

The University of São Paulo (USP) is the largest university in Brazil, with great relevance within the international academic scene. The campus of USP located in the city of São Carlos, counted in 2015, with 5,199 undergraduates, 2,579 postgraduates, 1,179 employees and 531 teachers, which adds a character of return and socio-environmental responsibility. Also, it consumes $161,541 \mathrm{~m}^{3} \cdot \mathrm{year}^{-1}$ of water, and $11.3 \mathrm{GWh} . y e a r^{-1}$, being 1191.22 KWh.person ${ }^{-1}$ of electricity (Paulo et al., 2010), in addition to $\mathrm{CO}^{2}$ emissions, waste generation, Natural resources and consumption of public monetary resources. In 2011/2013 a total of $36 \mathrm{~kg}$ of recyclable paper were collected on the São Carlos campus (USP- Recicla, 2013).

USP - São Carlos has the following units: Institute of Physics (IFSC), Institute of Chemistry (IQSC), Institute of Mathematical Sciences and Computation (ICMC), School of Engineering of São Carlos (EESC) and Institute of Architecture and Urbanism (IAU). As an example of the diversity of waste generation, according to Schalch (2014)

Table 2, specifically shows the amount of each residue produced. Table 2 describes quantitatively the waste generation of the campus.

Table 2. Qualitative and quantitative description of residues generated in USP-SC (Schalch et al., 2014)

\begin{tabular}{ll}
\hline Type of Waste & Amount \\
\hline Urban waste generated within the São Carlos Campus & $6325 \mathrm{Kg}^{-1}$ \\
Waste from the third party restaurants generated within the São Carlos Campus & $95 \mathrm{Kg}^{-1}$ \\
Pruning waste generated within the São Carlos Campus & $16 \mathrm{dumpster.month}^{-1} . \mathrm{trucks}^{-1}$ \\
Commercial Establishments and Service Providers waste generated within the São Carlos Campus & $0.74 \mathrm{~m}^{3}$. week $^{-1}$ \\
Chemicals waste generated within the São Carlos Campus of USP & $645 \mathrm{Kg} \cdot \mathrm{month}^{-1}$ \\
Workshop waste generated within the São Carlos Campus & $30 \mathrm{Kg}^{-1} \mathrm{month}^{-1}$ \\
Healthcare Waste generated within the São Carlos Campus & $0.65 \mathrm{~m}^{3} \cdot$ week $^{-1}$ \\
Civil Construction Waste generated within the São Carlos Campus & $162 \mathrm{~m}^{3} \cdot \mathrm{month}^{-1}$ \\
Geology Research Waste & $250 \mathrm{Kg}^{-1}$ month $^{-1}$ \\
\hline
\end{tabular}

Since USP has different units, and these have specific characteristics of generation and management of their residues, this reinforces the PNRS requirement for the elaboration of Solid Waste Management Plans for each unit of the university.

\subsubsection{USP São Carlos Case Study-Waste Management Analysis in Accordance to the PNRS' Requirements}

Table 2, elaborated with PNRS and field research data, shows the relationship between what is proposed by the PNRS, through the Criteria proposed to elaborate the Integrated Municipal Plans for Solid Waste Management (PMIGRS) and the management actions that occur within USP-São Carlos. 
Table 3. PNRS requirements checklist, and description of activities according to the USP-SC solid waste management diagnosis. Evaluation of the effectiveness of actions

\begin{tabular}{|c|c|c|}
\hline Responsibility Agent & PNRS Item & Evaluation \\
\hline São Carlos municipality & $\begin{array}{l}\text { Art. 19, Paragraph II; Art. 19, Paragraph III } \\
\text { Art. 19, Paragraph V; Art. 19, Paragraph XIII } \\
\text { Art. 19, Paragraph VII }\end{array}$ & $\begin{array}{l} \\
\bullet \\
0\end{array}$ \\
\hline USP-SC & $\begin{array}{l}\text { Art. 19, Paragraph I; Art. 19, Paragraph V; Art. 19, Paragraph IX; Art. 19, } \\
\text { Paragraph X } \\
\text { Art. 19, Paragraph IV; Art. 19, Paragraph XI; Art. 19, Paragraph XIV; Art. 19, } \\
\text { Paragraph XV; Art. 19, Paragraph XVI; Art. 19, Paragraph XVII; Art. 19, } \\
\text { Paragraph XVIII; Art. 19, Paragraph IXX } \\
\text { Art. 19, Paragraph VIII; Art. 19, Paragraph XII }\end{array}$ & 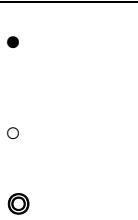 \\
\hline $\begin{array}{l}\text { Third party Incineration } \\
\text { Companies }\end{array}$ & $\begin{array}{l}\text { Art. 19, Paragraph XIII } \\
\text { Art. 19, Paragraph VII }\end{array}$ & ( \\
\hline
\end{tabular}

\section{Discussion}

The case study's qualitative-descriptive analysis is presented below for each PNRS requirement.

"Diagnosis of solid waste situation", Arct. 19, Paragraph I: USP-SC has a generation, disposal and final disposal of waste inventory. However, this diagnosis is not periodic. The PNRS requires the preparation of Municipal Plans for the Integrated Management of Solid Waste (PMGIRS), which contains the steps of diagnosis, and adequacy, and where odds can be noticed, decision-makers must apply corrective actions. Regarding the diagnostic stage in USP-SC, it was already performed by Schalch et al. (2014), which was a punctual and proactive action of a teacher/researcher, with no obligation.

"Identification of satisfactory areas for environmentally adequate final disposal of waste", Art. 19, Paragraph II and "Identification of the possibilities for the implementation of shared solutions with other Municipalities, considering, in the economies of scale criteria, proximity to established sites and ways of preventing environmental risks," Arct. 19, Paragraph III. Responsibility of the Municipal Master Plan.

"Identification of solid waste generators and subjects to management plans and actions of Reverse Logistics", Arct. 19, Paragraph IV: Carried out by the São Carlos Waste Inventory. Today USP has a battery collection program, where special bins are spread across several locations at the campus, once these containers are full, an agent collects and takes them to supermarkets, for reverse logistics process purpose. There is no institutional policy for reverse logistics of lamps.

"Operational Procedures and Minimum Specifications for Environmentally Appropriate Waste Disposal (Chemical and Biological Waste)", Arct. 19, Paragraph V: The chemical and biological waste treatment at USP-SC is responsibility of the Chemical Waste Laboratory (LRQ), there are actions to recover solvents, as well as adequate waste storage for disposal through incineration, the companies that perform this process return to the laboratory a legal document proving the proper disposal of the waste. Some laboratories do not trust the solvents recovered by the Laboratory of Chemical Waste, these laboratories prefer to buy new ones, which is a fragility of the public financing system. The LRQ gives recovery preference to large laboratories, forcing small laboratories to have their own recovery system.

"Indicators of operational and environmental performance of public services of urban cleaning and solid waste management", Arct. 19, Paragraph VI: The cleaning of the three areas of USP-SC campus is performed by third party companies and do not have performance Indicators.

"Rules for transportation and other stages of solid waste management", Arct. 19, Paragraph VII: Transportation of part of the waste is carried out by the city of São Carlos, all the collected volume is sent to the sanitary landfill of the city; Hazardous waste is transported by specialized companies and recyclables are destined to cooperatives. Batteries and lamps are collected by specific companies. However, the final destination of these wastes is not transparent.

"Definition of responsibilities for its implementation and operationalization", Arct. 19, Paragraph VIII: The USP Solid Waste Policy indicates that each Institute should compose a Council to manage its waste, decentralizing decision-making by city halls and the dean's office.

"Technical training programs and actions aimed at their implementation and operation", Arct. 19, Paragraph IX and "Environmental education programs and actions to promote the non-generation, reduction, reuse and 
recycling of solid waste", Arct. 19, Paragraph X: There are programs such as USP-Recicla, which has been operating in São Carlos since 1995 in Environmental Education to waste reduction, one of the products of this program is the Practical Guide for minimization and management of waste-USP São Carlos. In addition, it also has the PAP (Participating Learners) Program, which aims to incorporate sustainable principles and practices among university's staff, serving as an example for students and for society in general.

"Programs and actions for the participation of interested groups, especially cooperatives or other forms of recyclable materials collectors' association formed by low-income individuals", Arct. 19, Paragraph XI: At USP-SC, there are outreach programs dealing with Solid Waste: The CDCC program, whose focus of activities developed by the Center for Scientific and Cultural Disclosure are students and teachers of secondary and fundamental education. And, implanted in the Campus in 1997, the Small Citizen Project that serves 220 children from low-income families of São Carlos, with various cultural and educational activities.

"Mechanisms for the creation of sources of business, employment and income, through the valuation of solid waste", Arct. 19, Paragraph XII: It already appears in draft, which will be instituted by the USP Waste Management Policy.

"System for calculating the costs of rendering public services for urban cleaning and solid waste management", Arct. 19, Paragraph XIII: Residues produced at USP-SC that are sent directly to the landfill do not generate any cost to the university. However, for the treatment of chemical and biological waste that needs to be incinerated in a third-party company, the cost is covered by the laboratory itself, which obtains funding from sources of research and private initiative.

"Waste reduction, reuse, segregation and recycling goals, among others, with a view to reduce waste quantity sent to environmentally appropriate final disposal", Arct. 19, Paragraph XIV: It will be instituted by the USP Waste Management policy.

"Description of the forms and limits of the participation of local public authorities in the selective collection and reverse logistics, and other actions related to shared responsibility for the product life cycle", Arct. 19, Paragraph XV: Will be instituted by the USP Waste Management Policy.

"Means to be used for the control and supervision, at a local level, of the implementation and operationalization of solid waste management plans", Arct. 19, Paragraph XVI: Will be instituted by the USP Waste Management Policy.

"Preventive and corrective actions to be practiced, including monitoration program", Arct. 19, Paragraph XVII: Will be instituted by the USP Waste Management Policy.

"Identification of environmental liabilities related to solid waste, including contaminated areas, and respective sanitation measures", Arct. 19, Paragraph XVIII: Carried out by the Inventory of Residues of USP-São Carlos.

"Periodicity of its review, with priority being given to the period of validity of the municipal multiannual plan", Arct. 19, Paragraph IXX: Will be instituted by the USP Waste Management Policy.

The table 4 presents a description of what are the PNRS item and how the USP-SC complies with it.

Table 4. Evaluation description for each PNRS item

\begin{tabular}{ll}
\hline PNRS Item & Evaluation discription \\
\hline Art. 19, Paragraph I & $\begin{array}{l}\text { The waste diagnosis must be deployed yearly, according to PNRS' requirements. The USP-SC produces a yearly } \\
\text { based disgnosis within a course conducted by a teacher, although, this is a proactive initiative and is not } \\
\text { institutionalized to strengthen the initiative. }\end{array}$ \\
\hline Art. 19, Paragraph II & $\begin{array}{l}\text { The disposal must accomplish specific Brazilian Regulation Norms (NBR), with a set of operational criteria to } \\
\text { prevent socioenvironmental risks. }\end{array}$ \\
\hline Art. 19, Paragraph III & $\begin{array}{l}\text { The university complies with the requirements proposed by the PNRS, e.g. is the adequate disposal of light } \\
\text { bulbs, where the university directs them to the producer for recycling. }\end{array}$ \\
\hline Art. 19, Paragraph IV & $\begin{array}{l}\text { The PNRS sets that each laboratory is responsible for its hazardous waste management according to the waste } \\
\text { classification within the NBR criteria, respective to the waste level of hazardousness. }\end{array}$ \\
\hline Arct. 19, Paragraph V & $\begin{array}{l}\text { The PNRS sets that bruming and urban cleaning waste must be adequate disposed and if aplicable composting } \\
\text { must be carried. }\end{array}$ \\
\hline Art. 19, Paragraph VI & $\begin{array}{l}\text { The PNRS requires an official response by the companies that handle the waste final disposal, this document } \\
\text { must be stored and presented to Brazilian public health agencies in a regular basis. }\end{array}$ \\
\hline Arct. 19, Paragraph VIII & $\begin{array}{l}\text { The PNRS suggests that each unit, department, campus, parks and museum that compose the university must } \\
\text { elect a council that will handle the planning and implementation of waste policies and goals. The USP deployed } \\
\text { its own waste policy folowing the PNRS's directives. }\end{array}$ \\
\hline
\end{tabular}




\begin{tabular}{|c|c|}
\hline & \multirow{3}{*}{$\begin{array}{l}\text { The USP-SC already promotes awareness interventions with the USP Recicla recycling program and fulfills the } \\
\text { PNRS's requirements, plus, this program presents as a role model for other institutions due to its successfull } \\
\text { initiatives. This program has a strong relationship with the city recycling cooperative. }\end{array}$} \\
\hline Paragraph X & \\
\hline & \\
\hline & \\
\hline & \\
\hline & \multirow{3}{*}{$\begin{array}{l}\text { The USP-SC is in its final processes for the university's Waste Policy implementation, this policy brings the } \\
\text { election of committees to plan the mission and pursuit for unit, department, and museum to tackle a sound waste } \\
\text { management, with goal that best suits each reality. }\end{array}$} \\
\hline & \\
\hline & \\
\hline & $\begin{array}{l}\text { icy review, with elaboration of new goals and assessing its waste } \\
\text { s. }\end{array}$ \\
\hline $\begin{array}{lll}\text { Arct. } 19, \quad P \\
\text { XVIII }\end{array}$ & by \\
\hline Art. 19, Paragraph IXX & $\begin{array}{l}\text { PNRS } \\
\text { le. }\end{array}$ \\
\hline
\end{tabular}

\section{Final Considerations and Future Perspectives}

Many of the requirements proposed by the PNRS are the municipality's responsibility, this highlights the discussion that the university cannot be taken as an island, and its actions must transpose the limits of the academy and influence the society and the other way around. It also has a pivotal role in the discussion of sustainability, bearing the responsibility of increasing individuals' cultural awareness and knowledge, as well as proposing technological innovations and tools to direct society towards sustainable development. They have a responsibility to act in education and research, proposing technological innovation to improve and direct effective solutions for waste management, policy development, and dissemination of information and integration of the external community to create a sustainable future (de Souza et al., 2016).

USP-São Carlos does not have a waste management plan, however, as shown in Table 2, its management already occurs in a systematic way. This shows that the adequacy requirements proposed by the PNRS come to add an effective management. The publication of the PGRS-USP under the hierarchical umbrella of the PNRS comes to give institutional strength, providing political and legislative support for activities that already occur.

In addition, the university must be a management model for municipalities (Tu et al., 2015), by adapting to the PNRS requirements, through a dynamic and participative process, with continuous improvement and learning.

An institution can have an effective solid waste management, however, without an institutional legal framework, this management becomes fragile and its efficiency and effectiveness is vulnerable to the change of decision makers, thus, the of an Environmental Policy elaboration and a Policy with Focus on waste management, with well-defined plans and goals are a strong support tool.

This work's purpose was to analyze the University of São Paulo-São Carlos campus solid waste management according to the Brazilian National Solid Waste Policy requirements, to certify the capability of this policy to turn in to a support tool to enhance a university's waste management, since Brazilian universities do not have any legal specific framework to conduct this adequacy. This paper concludes that the Brazilian Solid Waste National Policy translates into a strong framework tool to support decision making for adequacy of environmentally sound management of Brazilian university campuses.

In this context, it is important to emphasize the similarity between university campuses and small cities in terms of waste generation diversity and the impacts on natural resources resulting from its variate activities of teaching, research, extension, laboratories, administrative processes, food, housing, transport and maintenance. However, regard to the application of the PNRS's requirements, it must be noted that municipalities are obligated to do it, although, universities that have the same potential pollutant profile, do not have this obligation. This means a lack of legal support for a university to direct its waste management activities into a more environmentally sound path.

Innovative strategies and technologies must be deployed and applied within universities to tackle a sound and optimized waste management and daily operational activities. Assessments regard the opportunities can be divided in universities' main operational dimensions, as it follows:

1) Primary and secondary wastewater reuse: The university uses a high amount of water per day to fulfill a diverse range of activities, in this context, wastewater with different physical and chemical carachteristics is generated, and other to send it to disposal, this wastewater has potential, with previous adequate treatment, to be 
used in campus irrigation, greywater generated can be used within buildings and distributed to campus surroundings for cleaning purposes.

2) Recycling physical interventions: Studies regard bins amount and allocation, collectors' best routes and community cultural aspescts must be conducted to guarantee an effective recycling program. The campus must be a place for the surrounding community waste collection, as specific bins for glass, plastic, paper, aluminum, batteries, wastes of hardware and domestic appliance. In this context, the campus will serve as a hub and mediator for recyclables adequate disposal by the community and further collection by third party companies.

3) Energy consumption reduction: Initiatives and innovation regard electricity generation must take place within the university facilities, these initiatives must also be presentated to the community as tools to decrease natural resources consumption and awareness initiatives will allow them to integrate the program, reinforcing their importante role in energy consumption decrease.

4) Organic waste composting: A large amount of organic waste is generated daily, with high potential for composting, the USP São Carlos campus has a program where all the composted waste turned in fertilizer are used in the municipal garden that produces vegetables for surrounding schools. Authors suggest the institutionalization through a policy implementation so this program is not discontinuated due to decision makers change.

5) Community awareness: The USP Recicla recycling program has a history of successful awareness interventions within the university that translates in amount of waste recycled increase. In this sense, financial and human resources must be directed to improve the USP Recicla recycling program to strengthen and to support its awareness and environmental education interventions.

USP's waste policy is being deployed, based on PNRS' requirements, this confirms the PNRS' potential as a framework for universities waste management policies elaboration, although, a key factor for success of its enactment and functionality is the diverse university stakeholders' engagement on its elaboration. The policy has a strong potential, tackling to foster the insertion of sustainability, institutionally transversal, and functional structure, integrating processes and objectives that introduce culture and values related to sustainability for its community, and capable of reflecting paradigm shifts, from the rectory and university's city hall to classrooms and throughout university walls.

Finally, USP — São Carlos, even though it does not have an institutionalized management plan, the system is functioning, however, with some adjustments that must be corrected, being foreseen to be adapted after USP-SWP enactment, further studies are required ex-post its enactment to assess the waste policy impacts at the university.

\section{Acknowledgments}

Researchers would like to thank the Brazilian National Council for Scientific and Technological Development for the financial aid \#165627/2014-0.

\section{References}

Adeniran, A. E., Nubi, A. T., \& Adelopo, A. O. (2017). Solid waste generation and characterization in the University of Lagos for a sustainable waste management. Waste Management. Article in press. https://doi.org/10.1016/j.wasman.2017.05.002

Alshuwaikhat, H. M., \& Abubakar, I. (2008). An integrated approach to achieving campus sustainability: assessment of the current campus environmental management practices. Journal of Cleaner Production, 16(16), 1777-1785. http://doi.org/10.1016/j.jclepro.2007.12.002

Amaral, R., Heras, D. B., Leme, P., \& Malheiros, T. F. (2013). Aplicabilidade da pegada ecológica em contextos universitários. Indicadores de sustentabilidade e gestão ambiental. Barueri, SP: Manole, 495-522.

Amasuomo, E., \& Baird, J. (2016). Solid Waste Management Trends in Nigeria. Journal of Management and Sustainability, 6(4), 35. https://doi.org/10.5539/jms.v6n4p35

Armijo de Vega, C., Ojeda Benítez, S., \& Ramírez Barreto, M. E. (2008). Solid waste characterization and recycling potential for a university campus. Waste Management, 28. http://doi.org/10.1016/j.wasman.2008.03.022

Baldwin, E., \& Dripps, W. (2012). Spatial characterization and analysis of the campus residential waste stream at a small private liberal arts institution. Resources, Conservation and Recycling, 65, 107-115. http://doi.org/10.1016/j.resconrec.2012.06.002 
Baxter, P., \& Jack, S. (2008). Qualitative case study methodology: Study design and implementation for novice researchers. The Qualitative Report, 13(4), 544-559.

Belkhir, L. (2015). The Innovation Levers to Sustainability Management: Entrepreneurship, Design and Policy. Journal of Management and Sustainability, 5(1), 10. http://dx.doi.org/10.5539/jms.v5n1p10

Brazil. Política Nacional de Resíduos Sólidos (Solid Waste National Policy), Law No 12.305. (2010). Retrieved from http://www.planalto.gov.br/ccivil_03/_ato2007-2010/2010/lei/112305.htm

Broman, G. I., \& Robèrt, K. H. (2017). A framework for strategic sustainable development. Journal of Cleaner Production, 140, 17-31. https://doi.org/10.1016/j.jclepro.2015.10.121

de Souza, R. G., Clímaco, J. C. N., Sant'Anna, A. P., Rocha, T. B., do Valle, R. D. A. B., \& Quelhas, O. L. G. (2016). Sustainability assessment and prioritisation of e-waste management options in Brazil. Waste Management, 57, 46-56. https://doi.org/10.1016/j.wasman.2016.01.034

Drever, E. (1995). Using Semi-Structured Interviews in Small-Scale Research. A Teacher's Guide.

Duarte, C. G., Gaudreau, K., Gibson, R. B., \& Malheiros, T. F. (2013). Sustainability assessment of sugarcane-ethanol production in Brazil: A case study of a sugarcane mill in São Paulo state. Ecological Indicators, 30, 119-129. http://doi.org/10.1016/j.ecolind.2013.02.011

Faleschini, F., Zanini, M. A., Pellegrino, C., \& Pasinato, S. (2016). Sustainable management and supply of natural and recycled aggregates in a medium-size integrated plant. Waste Management, 49, 146-155. https://doi.org/10.1016/j.wasman.2016.01.013

Galpin, T., Whitttington, J. L., \& Bell, G. (2015). Is your sustainability strategy sustainable? Creating a culture of sustainability. Corporate Governance, 15(1), 1-17. https://doi.org/10.1108/CG-01-2013-0004

Hoornweg, D., \& Bhada-Tata, P. (2012). What a waste: a global review of solid waste management. Urban Development Series Knowledge Papers, 15, 1-98.

Lozano, R., Lozano, F. J., Mulder, K., Huisingh, D., \& Waas, T. (2013). Advancing higher education for sustainable development: international insights and critical reflections.

Mallak, S. K., Ishak, M. B., Mohamed, A. F., \& Abdullah, S. (2014). Barriers to Practice of Non-Hazardous Solid Waste Minimization by Industries in Malaysia. Journal of Management and Sustainability, 4(1), 154. http://dx.doi.org/10.5539/jms.v4n1p154

Marans, R. W., Callewaert, J., \& Shriberg, M. (2015). Enhancing and monitoring sustainability culture at the University of Michigan. In Transformative Approaches to Sustainable Development at Universities (pp. 165-179). New York: Springer International Publishing. https://doi.org/10.1007/978-3-319-08837-2_12

Mason, I. G., Brooking, A. K., Oberender, A., Harford, J. M., \& Horsley, P. G. (2003). Implementation of a zero waste program at a university campus. Resources, Conservation and Recycling, 38(4), 257-269. http://doi.org/10.1016/S0921-3449(02)00147-7

Mauser, W., Klepper, G., Rice, M., Schmalzbauer, B. S., Hackmann, H., Leemans, R., \& Moore, H. (2013). Transdisciplinary global change research: the co-creation of knowledge for sustainability. Current Opinion in Environmental Sustainability, 5(3-4), 420-431. http://doi.org/10.1016/j.cosust.2013.07.001

Mesjasz-Lech, A. (2014). Municipal waste management in context of sustainable urban development. Procedia-Social and Behavioral Sciences, 151, 244-256. https://doi.org/10.1016/j.sbspro.2014.10.023

Schalch, V. (2014). Diagnóstico da Geração, Gestão e Gerenciamento de Resíduos Sólidos na USP—São Carlos.

Smyth, D. P., Fredeen, A. L., \& Booth, A. L. (2010). Reducing solid waste in higher education: The first step towards "greening" a university campus. Resources, Conservation and Recycling, 54, 1007-1016. https://doi.org/10.1016/j.resconrec.2010.02.008

Stark, R., \& Lindow, K. (2017). Sustainability Dynamics. In Sustainable Manufacturing (pp. 21-31). New York: Springer International Publishing. https://doi.org/10.1007/978-3-319-48514-0_2

Tangwanichagapong, S., Nitivattananon, V., Mohanty, B., \& Visvanathan, C. (2017). Greening of a campus through waste management initiatives: Experience from a higher education institution in Thailand. International Journal of Sustainability in Higher Education, 18(2), 203-217. https://doi.org/10.1108/IJSHE-10-2015-0175

Thomas, E., \& Magilvy, J. K. (2011). Qualitative rigor or research validity in qualitative research. Journal for Specialists in Pediatric Nursing, 16(2), 151-155. http://doi.org/10.1111/j.1744-6155.2011.00283.x 
Tom, W., Kim, C., Wim, L., Joke, V., Rodrigo, L., \& Tarah, W. (2012). Sustainable Higher Education-Understanding and Moving Forward. Flemish Government-Environment, Nature and Energy Department.

Too, L., \& Bajracharya, B. (2015). Sustainable campus: Engaging the community in sustainability. International Journal of Sustainability in Higher Education, 16(1), 57-71. https://doi.org/10.1108/IJSHE-07-2013-0080

Tu, Q., Zhu, C., \& McAvoy, D. C. (2015). Converting campus waste into renewable energy-A case study for the University of Cincinnati. Waste Management, 39, 258-265. https://doi.org/10.1016/j.wasman.2015.01.016

USP Recicla—São Carlos—Relatório Bianual—Julho/2011 a julho/2013. p. 132. Retrieved from http://www.projetosustentabilidade.sc.usp.br/index.php/content/download/3656/39404/version/1/file/USPR ecicla_2011-2013Final.pdf

Yuan, X., \& Zuo, J. (2013). A critical assessment of the Higher Education For Sustainable Development from students' perspectives-a Chinese study. Journal of Cleaner Production, 48, 108-115. http://doi.org/10.1016/j.jclepro.2012.10.041

Zain, S. M., Basri, N. E. A., Basri, H., Zakaria, N., Elfithri, R., Ahmad, M., ... Khan, I. Z. I. (2012). Focusing on Recycling Practice to Promote Sustainable Behavior. Procedia-Social and Behavioral Sciences, 60, 546-555. https://doi.org/10.1016/j.sbspro.2012.09.421

Zurbrügg, C., Gfrerer, M., Ashadi, H., Brenner, W., \& Küper, D. (2012). Determinants of sustainability in solid waste management-The Gianyar Waste Recovery Project in Indonesia. Waste Management, 32(11), 2126-2133. https://doi.org/10.1016/j.wasman.2012.01.011

\section{Copyrights}

Copyright for this article is retained by the author(s), with first publication rights granted to the journal.

This is an open-access article distributed under the terms and conditions of the Creative Commons Attribution license (http://creativecommons.org/licenses/by/4.0/). 